\title{
Electrophysical characteristics of LEDs based on GaN epitaxial films
}

\author{
P. Ph. Oleksenko, G. A. Sukach, P. S. Smertenko, \\ S. I. Vlaskina, A. B. Bogoslovskaya, I. O. Spichak \\ Institute of Semiconductor Physics, NAS Ukraine, 45 prospekt Nauki, Kyiv, 252028, Ukraine \\ Tel.380(44)2656477; Fax 380(44)2658342; E-mail:smertenk@class.semicond.kiev.ua
}

\section{H. Shin}

Dongguk University, Chung-ku, Pildong 3-26, Seoul,South Korea,

tel.822278 3429; fax.822278 4519; e-mail shin0313@chollian.dacom.co.kr

\begin{abstract}
Forward and reverse current-voltage (I-V) characteristics of light emitting diodes based on $\mathrm{GaN}$ epitaxial films were investigated by differential spectroscopy. This technique is based on calculating the differential slope of the I-V curve in the log-log scale in the following form: $\alpha=\mathrm{d} \lg \mathrm{i} / \mathrm{d} \lg \mathrm{V}$ and $\gamma=\mathrm{d} \lg \alpha / \mathrm{d} \lg \mathrm{V}$. The main peculiarity of reverse I-V curves is the absence of rectification. The I(V) dependence can be approximated as $\mathrm{i} \sim \mathrm{V}^{3}$ at low bias and $\mathrm{i} \sim \mathrm{V}^{4}$ at high bias. These functions correspond to a high and superhigh level of double injection of current carriers, respectively. The forward current depends on voltage exponentially, with the ideality factor ranging from 6 to 8 under the bias of up to 1.5 $\mathrm{V}$. The $\alpha(\mathrm{V})$ dependence has two maxima corresponding to a change of the charge flow mechanism from carrier diffusion to the field mechanism in the first case and to overcoming the recombination barrier in the second case. The second maximum is followed by light emission. Behavior of the I-V curves in temperature range from $150 \mathrm{~K}$ to $400 \mathrm{~K}$ is discussed and compared to that of spectral, kinetic, and power-current characteristics measured in the same temperature range.
\end{abstract}

Keywords: gallium nitride, light emission, current-voltage characteristic, double injection

Paper received 10.09.98; revised manuscript received 14.10.98; accepted for publication 28.10.98.

\section{Introduction}

Recent years have been marked with a burst of interest to GaN-based compounds, which showed much promise as a material for commercial light-emitting diodes (LED's) operating in the violet range. This became possible due to the great progress in the technology of GaN cleaning and doping, allowing both $\mathrm{n}$ - and $\mathrm{p}$-type conductivity (and thus a p$\mathrm{n}$-junction) to be achieved. Some laboratories (in USA and Japan) have manufactured experimental samples of LED's and lasers emitting light in the blue-violet range (370$450 \mathrm{~mm}$ ) due to $\mathrm{Si}$ and $\mathrm{Mg}$ (or Zn) doping [1-2]. Structural, electrical, optical and other properties, energy diagrams and properties of the most relevant dopants were investigated [1]. The temperature coefficient of the band gap $[3,4]$, the temperature coefficient of thermal expansion [5], heat conductivity [6] and the temperature of p-n-junction overheating by current flow were determined [7]. However, until recently, the effect of thermal injection processes on the charge flow and on the transformation of radiative recombination centers in this kind of LED's has not been investigated. Some of these problems have become the subject of the present work.

\section{Experimental results and discussion}

GaN-based samples containing light-emitting p-n-junctions were manufactured as described in [8]. They were investigated in detail in the temperature range from $290 \mathrm{~K}$ to $360 \mathrm{~K}$, which is most relevant frob the viewpoint of technical application.

Fig. 1 shows forward and reverse $\mathrm{I}-\mathrm{V}$ characteristics of a sample under investigation and their differential representation in the form $\alpha=d \lg i / d \lg V$. This representation demonstrates the power law dependence $i(V)=V^{\alpha}$ in the sections where the differential slope $\alpha=$ const. Fig. 1 shows no rectification under the reverse bias (only a weak rectification is observed at a voltage lower than $0.3 \mathrm{~V}$ ) at room temperature. To the contrary, this curve is superlinear with a differential slope $\alpha=3$ and $\alpha=4$. These values of the I-V logarithmic slope indicate a high $(\alpha=3)$ and superhigh $(\alpha=4)$ injection of majority carriers into the high-resistance layer of the structure $[9,10]$. Under the forward bias, I-V curves can be described by the exponential law. However, in this domain the ideality coefficient $m$, defined as $m=e V / \alpha k T$, has the values ranging from 6 to 8 , thus indi- 


\section{P. Ph. Oleksenko et al.: Electrophysical Characteristics of LEDs based on GaN...}

cating that the forward I-V curve cannot be described by the Schockley-Noice-Saa theory. Also, this section of the curve shows no sign of the tunneling current component (in its presence, $\alpha$ should be equal to 4 ). We would like to point out that for semiconductors with a wide band gap $E_{g}$ (for $\left.\mathrm{GaN} E_{g}=3,36 \mathrm{eV}\right)$, the conventional theory of a p-n-junction can should be used with certain caution because of the low values of the minority carrier lifetimes $\tau$ (see below) and mobilities $\mu$ [1], which results in a violation of the condition $L_{D}>L_{e}$ (were $L_{D}$ and $L_{e}$ are the diffusion and Debye screening lengths, respectively). As for the temperature dependences of the differential slope of the forward and reverse I-V curves, it should be noted that throughout the temperature range examined (from $150 \mathrm{~K}$ to $360 \mathrm{~K}$ ) no remarkable changes of the current flow mechanisms occur. However, at lower temperatures the point where the behavior of current changes from ohmic to injection shifts to lower voltages. Obviously, this is caused by the change of the band gap width with temperature.

Figs. 2 and 3 show the electroluminescence spectra of LED's measured for different currents at $\mathrm{T}=291 \mathrm{~K}$ (fig. 2) and for different temperatures at $i=30 \mathrm{~mA}$ (fig. 3). The halfwidth of the emission band is shown in fig. 4 as a function of current in the ultraviolet $\left(h v_{\max 1}=3.36 \mathrm{eV}\right.$ at $\left.\mathrm{j} \rightarrow \infty\right)$ and violet $\left(h v_{\max 2}=2.28 \mathrm{eV}\right.$ at $\left.\mathrm{j} \rightarrow \infty\right)$ ranges, respectively. It is seen from the figures that the relative intensity of the first band $\left(I_{1}\right)$ rises with respect to that of the second band $\left(I_{2}\right)$ with the increase of current $i$. At $i \geq 15 \mathrm{~mA}$ this process is accelerated due to the saturation and then decrease of $I_{2}$. The growth of temperature intensifies this process due to a stronger thermal quenching of the second band intensity $I_{2}$ [7].

The onset of a high-intensity violet light emission was detected at $i=0.1 \mathrm{~mA}$. However, the peculiarities of the I-V and $\alpha(V)$ dependences observed at $V=0.8 \mathrm{~B}$
( $i \sim 10^{-8} \mathrm{~A}$ ) suggest that the main location of recombination shifts from the cathode region to the anode region, and that the minority carrier injection enhances. In our opinion, this is one of the premises for subsequent light emission. At this bias, the forward current begins to exceed the reverse one. There are two maxima after the exponential section of the $\alpha(V)$ dependence. The first maximum indicates the transition from the diffusion to field mechanism of charge flow, whereas the second one can be attributed to overcoming the high recombination barrier, after which the emission of light begins. The absence of any significant dependence of the I-V slope on the temperature suggests the field (or even the tunnel) mechanism of charge transport. The shift of the I-V curve to larger currents (at higher temperatures) correlates with a decrease of $t$ after thermal injection treatment (see below).

Let us analyze in more detail the influence of thermal injection factors on $I_{2}$, This emission band is widely used for design of LED's emitting in the violet region. At low excitation levels, the value of energy at the maximum of the $I_{2}$ band is minimal. Increase of $i$ up to $15 \mathrm{~mA}$ shifts $h v_{\max 2}$ to higher energies (shorter wavelengths). This is caused mainly by an increase in the concentration of nonequilibrium minority carriers. Such a dependence cannot be explained by recombination of two charge carriers, of which at least one is free. However, it is well known both experimentally and theoretically [11] for recombination of two bonded charge carriers. An electron localized at a donor and a hole localized at an acceptor are called a donor-acceptor pair (DAP). In this case, with an increase of the excitation level, the DAP's in which the donor and acceptor located far apart («longliving» configurations), that are responsible for emission of long-wave photons, are more quickly saturated than «close» DAP's because of the lower probability of the interimpurity transfer

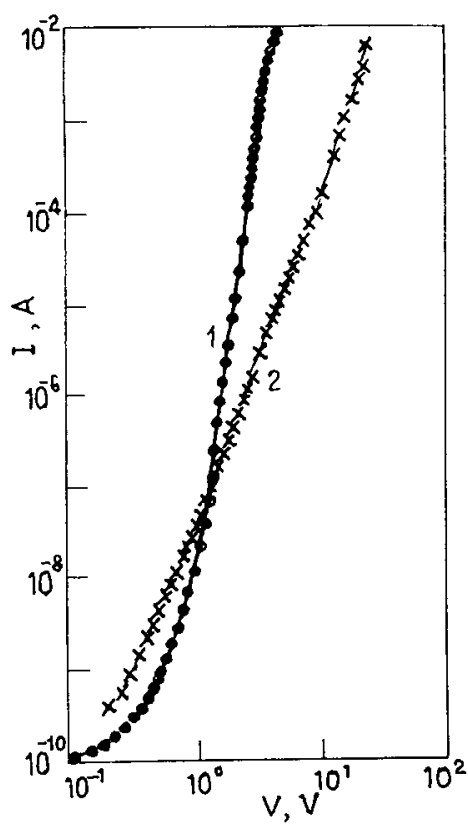

a
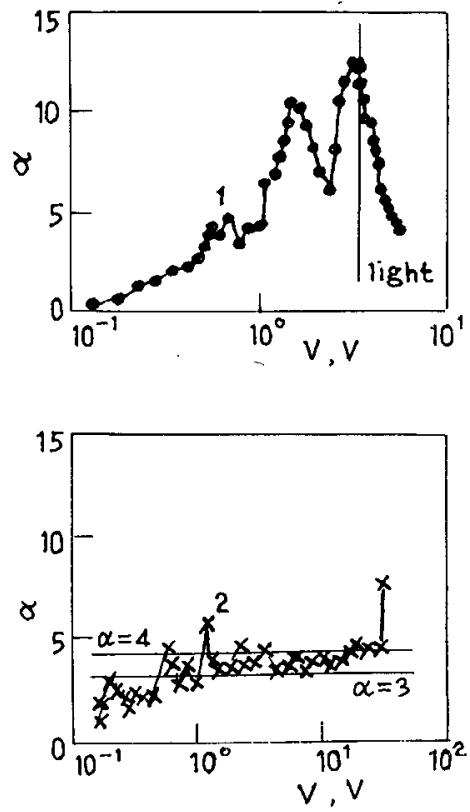

b
Fig. 1. Typical forward (1) and reverse (2) I-V curves of GaN-based $\mathrm{p}-\mathrm{n}$ - junctions at $\mathrm{T}=291 \mathrm{~K}$. The inserts show the dependence $\delta(\mathrm{V})$ of the voltage in case of forward (a) and reverse (b) bias. 


\section{P. Ph. Oleksenko et al.: Electrophysical Characteristics of LEDs based on GaN...}

$\mathrm{W} \approx \exp (-2 \mathrm{r} / \mathrm{a})$

where $r$ is the distance between the donor and acceptor, and $a$ is the greater one of the electron and hole Bohr radii. In the current range from $15 \mathrm{~mA}$ to $50 \mathrm{~mA}$, the position of the DAP band maximum is essentially unchanged, and with a further increase of $i$ shifts to longer wavelenghths. The latter is caused by thermal injection heating of the region where the DAP emission is generated, whereas the stable position of $h v_{\max 2}$ results from the competition between the abovementioned heating and a mechanism associated with an increase of the excitation level of the system.

Analysis of the shape of the DAP band shows that, in accordance with theory [11], at low excitation currents $(i \leq 1 \mathrm{~mA})$ it is broadened due to the growth of the share of its long-wave part.

The halfwidth of the band in these conditions is $420 \mathrm{meV}$. This is due to the transfer of electrons from shortliving to longliving configurations. As the current increases up to $20 \mathrm{~mA}$, the halfwidth of the DAP band decreases insignificantly (down to $400 \mathrm{meV}$ ) due to a decrease in the intensity of the long-wave part of the $I_{2}$ band. In the current range from 20 to $50 \mathrm{~mA}$, the halfwidth of this band increases insignificantly because of the enhancement of the longwave part, but does not reach the level observed at a low $(i<1 \mathrm{~mA})$ current. At $i>50 \mathrm{~mA}$, the spectrum changes significantly due to the growth of the long-wave part of this band, and the halfwidth increases sharply from $400 \mathrm{meV}$ (at $i=50 \mathrm{~mA}$ ) to $440 \mathrm{meV}$ (at $i=60 \mathrm{~mA}$ ), which is caused by the effect of the thermal injection current (see fig. 4).

Analysis of the temperature dependence of emission band $\left(I_{2}\right)$ shape in the range from 20 to $80^{\circ} \mathrm{C}$ shows that both at low $(i=1 \mathrm{~mA})$ and at high $(i=10 \mathrm{~mA})$ current (i.e. excitation level) it is unchanged. This indicates the absence of thermal injection of both electrons and holes in such structures [11]. Energies of the levels (both acceptors and donors) that which form DAP's are high, which agrees with the data known from literature $[1,5]$.

As for the temperature dependence of the band 1, its width is practically unchanged for the current ranging from

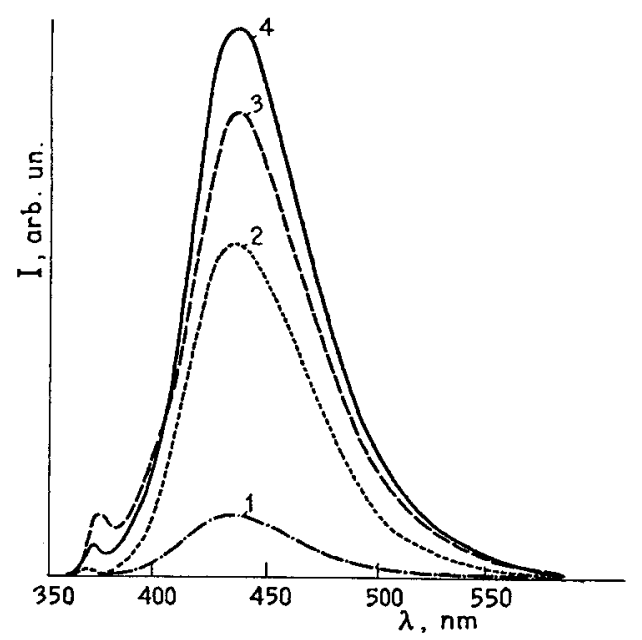

Fig. 2. Electroluminescence spectra of a $\mathrm{GaN}$ diode at $\mathrm{T}=291 \mathrm{~K}$ and various current values, mA: $1-2,2-10,3-50,4-30$.
0.1 to $30 \mathrm{~mA}$, which is typical for the band-to-band transfer. Further increase of the current results in a significant widening of this band ( $110 \mathrm{meV}$ at $i=60 \mathrm{~mA})$. That is caused by the thermal injection heating of LED's active area.

Analysis of the electroluminescence kinetics measured at pulse currents $(>50 \mathrm{~mA})$ shows that its decay is nonexponential (especially, at the initial stage). At first, emission from the shortliving pairs occurs, and only in the curve tail the decay is close to exponential. At higher excitation levels, the EL decay is accelerated. The duration of this process does not exceed 100-150 sec (with a long tail of the relaxation curve, caused by the longliving DAP recombination). Therefore, most of the charge carriers localized on the donors and acceptors recombine through shortliving configurations (the low-radius DAP). In our opinion, this situation results from the fact that most of the electrons and holes localized on the large-radius DAP's transfer through thermal exchange with appropriate bands (especially, this applies to electrons) to the short-radius DAP's. The character of kinetics shows that the main channel of minority carrier recombination is irradiative, i.e. the internal quantum yield of irradiation is close to 1 .

Measurements of the effective lifetime of minority carriers made by the technique of switching the $p$-n-junction from forward to reverse bias [12] allow estimating the effective life time of charge carriers associated with their diffusion and spreading. These measurements show that the value of $\tau$ changes in the range from 3 to $5 \mathrm{nsec}$, and drops when current increases. The decrease of $\tau_{\text {ef }}$ with an increase of the excitation level indicates a significant compensation of the $\mathrm{n}$ - and p-regions of the LED material. As t was only slightly higher than the sensitivity of the measurement system (2$3 \mathrm{nsec}$ ), we were not able to measure the temperature dependence of $t$.

\section{Conclusion}

The effect of thermal injection heating of LED's on their $\mathrm{I}-\mathrm{V}$ characteristics and electroluminescence spectra (especially the band associated with recombination via donor-acceptor pairs) was analyzed.

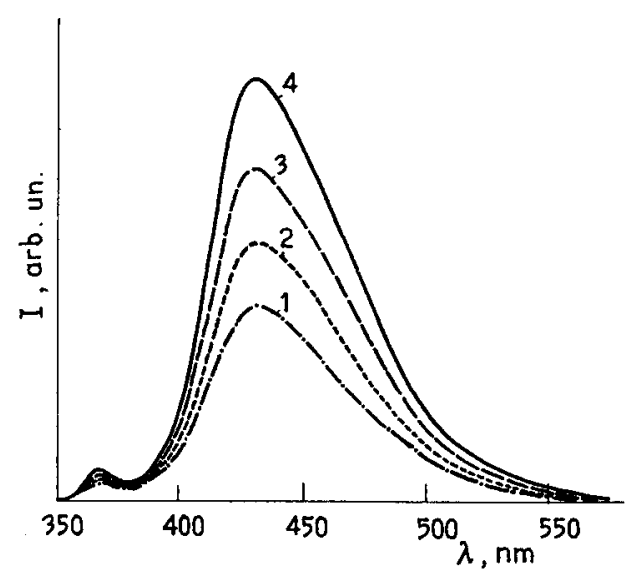

Fig. 3. Electroluminescence spectra at $i=30 \mathrm{~mA}$ and various temperatures: $1-353 \mathrm{~K}, 2-333 \mathrm{~K}, 3-313 \mathrm{~K}, 4-291 \mathrm{~K}$. 


\section{P. Ph. Oleksenko et al.: Electrophysical Characteristics of LEDs based on GaN...}

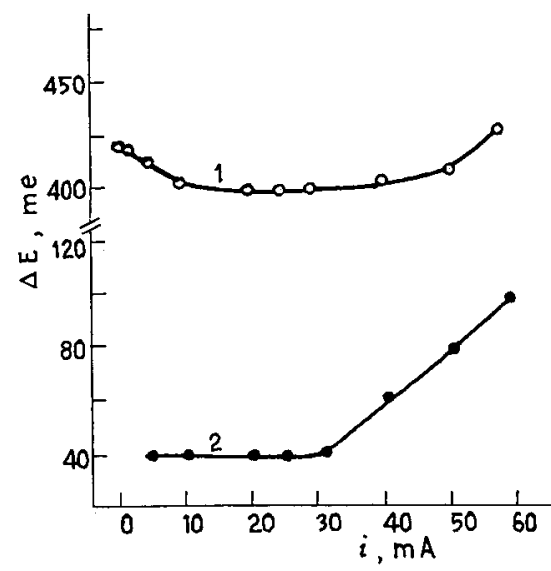

Fig. 4. Dependence of the DAP (1) and band-to-band (2) emission band halfwidth on current at $\mathrm{T}=291 \mathrm{~K}$.

The temperature (in the range from 100 to $350 \mathrm{~K}$ ) was found to have no significant effect on the mechanisms of charge carrier injection and recombination.

It was shown that the main mechanism of recombination is radiative recombination via DAP. This is indicated both by the nonexponential EL decay curve and the EL spectra.
It was also found that the DAP recombination does not change its intensity with an increase of temperature and current. However, faster saturation of the DAP takes place, because of its lower probability.

\section{References}

1. Strite S., Markoc H.// J. Vac. Scl. Technol.-1992.- B10, N4. - P. 1237-1265.

2. McDonald J. A. // III-VS Review.-1996.-9, N1.-P. 52-57.

3. Pankove J. I., Berkeyheiser J. E., Maruska H. P., Wittke J.// Solid State Commun.-1970.-8 .-P. 1051-1056.

4. Matsumoro T., Aoika M. // Jpn. Appl. Phys.-1974.-13 .-P. 1804 1808.

5. Maruska P., Tietjen J. J.// Appl. Phys. Lett.-1969.-15 .-P. 327-330.

6. Sichel K., Pankove J. I.// J. Phys. Chem. Solids.-1977.-38 - P. 330-336.

7. Svechnikov S. V., Oleksenko P. F., Sukach G. A., Smertenko P. S. Vlaskina S. I., Gromashevski V. L. // Materials Science and Engineering.-1997.-B50.-P. 319-321.

8. Edmond J., Kong H.-S., Leonard M., Bulman G., Negley G.// Proc. Int. Conf. on Carbide and Related Materials, Japan, Kyoto.-1995. -P. 504-509.

9. Lampert M., Mark P. Current injection in solids.- NY, Lnd.: Acad. Press, 1970

10. Zyuganov A. N., Svechnikov S.V Injection-contact phenomena in semiconductors.- Kiev: Naukova dumka, 1981

11. Levanyuk A. P., Osipov V. V./ UFJ.-1981.-133, No 3.-P. 427-477.

12. Nosov Yu. R. Physical principles of the semiconductor diode operation in impulse regime.- Moscow: Science, 1968.

\section{ДОСЛІДЖЕННЯ ЕЛЕКТРОФІЗИЧНИХ ХАРАКТЕРИСТИК СВД НА ОСНОВІ GaN ЕПІТАКСІЙНИХ ПЛІВОК}

П. Ф. Олексенко, Г. О. Сукач, П. С. Смертенко, С. І. Власкіна, А. Б. Богословська, І. А. Спічак, Д. Х. Шін* Інститут фізики напівпровіднків НАН Украӥни

*Донгук Університет, Південна Корея

Резюме. Прямі та зворотні вольт-амперні характеристики (BAX) світловипромінюючих діодів на основі GaN епітаксійнних плівок досліджено методом диференційної спектроскопії. Основу цього методу складає визначення диференційного нахилу кривої в подвійному логарифмічному масштабі в вигляді $\alpha=\mathrm{d} \lg \mathrm{i} / \mathrm{d} \lg \mathrm{V}$ та $\gamma=\mathrm{d} \lg \alpha / \mathrm{d} \lg \mathrm{V}$. Основною особливістю зворотної ВАХ $є$ відсутність випрямлення. Виявлено апроксимації ВАХ $i \sim V^{3}$ та $i \sim V^{4}$ в областях низького та високого зміщення, відповідно. Це відповідає високому та надвисокому рівням подвійної інжекції носіїв струму, відповідно. Пряма ВАХ показує експоненційну поведінку з фактором ідеальності від 6 до 8 в області зміщень до 1.5 В. Потім на залежності $\alpha(\mathrm{V})$ мають місце два максимуми, які відповідають зміненню механізму струмопроходження від дифузійного струму до польової емісії в першому випадку та подоланню рекомбінаційного бар'єру у другому. Тільки після другого максимуму починається випромінювання світла. Обговорюється поведінка ВАХ в температурному діапазоні від $150 \mathrm{~K}$ до $400 \mathrm{~K}$. Проведено порівняння ВАХ та спектральних, кінетичних і ампер-яскравістних характеристик в тому ж температурному діапазоні.

\section{ИССЛЕДОВАНИЯ ЕЛЕКТРОФИЗИЧЕСКИХ ХАРАКТЕРИСТИК СВД НА ОСНОВЕ GаN ЭПИТАКСИАЛЬНЫХ ПЛЕНОК}

\section{П. Ф. Олексенко, Г. О. Сукач, П. С. Смертенко, С. И. Власкина, А. Б. Богословская, И. А. Спичак, Д. Х. Шин* Институт физики полупроводников НАН Украины *Донгук Университет, Южнная Корея}

Резюме. Прямые и обратные вольт-амперные характеристики (BAX) светоизлучающих диодов на основе GaN эпитаксиальных пленок исследованы методом дифференциальной спектроскопии. Основу этого метода составляет определение дифференциального наклона кривой в двойном логарифмическом масштабе в виде $\alpha=\mathrm{d} \lg \mathrm{i} / \mathrm{d} \lg \mathrm{V}$ и $\gamma=\mathrm{d} \lg \alpha / \mathrm{d} \lg \mathrm{V}$. Основной особенностью обратной ВАХ является отсутствие выпрямления. Выявлены аппроксимации ВАХ $i \sim V^{3}$ и $i \sim V^{4}$ в областях низкого и высокого смещения, соответственно. Это обусловлено высоким и сверхвысоким уровнем двойной инжекции носителей тока, соответственно. Поведение прямой ВАХ показывает экспоненциальный характер с фактором идеальности от 6 до 8 в области смещений до $1.5 \mathrm{~B}$. Затем на зависимости $\alpha(\mathrm{V})$ имеются два максимума, которые соответствуют изменению механизма токопрохождения от диффузионного тока к полевой эмиссии в первом случае и преодолению рекомбинационного барьера во втором. Только после второго максимума начинается излучение света. Обсуждается поведение ВАХ в температурном диапазоне от $150 \mathrm{~K}$ до $400 \mathrm{~K}$. Проведено сравнение ВАХ с спектральными, кинетическими и ампер-яркостными характеристиками в том же температурном диапазоне. 